\title{
STAFF TURNOVER COSTS: IN SEARCH OF ACCOUNTABILITY
}

\author{
Chris GUILDING \\ Tourism, Sport \& Service Research Centre \\ Griffith University - Gold Coast Campus \\ Queensland \\ AUSTRALIA \\ c.guilding@griffith.edu.au \\ Dawne LAMMINMAKI \\ Department of Accounting Finance and Economics \\ Griffith University - Gold Coast Campus \\ Queensland \\ AUSTRALIA \\ d.lamminmaki@griffith.edu.au \\ and \\ Lisa McMANUS \\ Department of Accounting Finance and Economics \\ Griffith University - Gold Coast Campus \\ Queensland \\ AUSTRALIA \\ 1.mcmanus@griffith.edu.au
}

Corresponding author:

Professor Chris Guilding

Department of Tourism, Leisure, Hotel and Sport Management

Griffith University - Gold Coast Campus

Queensland 4222

AUSTRALIA

Tel: 01161755528790

Fax: 01161755528507 


\title{
STAFF TURNOVER COSTS: IN SEARCH OF ACCOUNTABILITY
}

\begin{abstract}
The nature of staff turnover accounting procedures in a labor intensive context has been examined by conducting interviews with twenty eight managers in large three to five star hotels and two theme parks. It was found that the main staff turnover accountability procedures adopted involve monthly departmental reporting of staff turnover percentage levels and also the conduct of exit interviews. A degree of staff turnover costing was noted, although this practice was not extensively applied. Most interviewees supported the notion of allocating staff turnover costs to those operating departments experiencing the turnover. A muted form of this practice was observed in one hotel, however most interviewees had never contemplated or heard of the practice. Agency theory has been utilized as a framework for structuring a range of observed and potential staff turnover accountability relationships.
\end{abstract}

Keywords: Hotel staff turnover costs; cost allocation, exit interviews. 


\section{STAFF TURNOVER COSTS: IN SEARCH OF ACCOUNTABILITY}

\section{Introduction}

In the hospitality management and also human resource management literatures, frequent reference is made to terms such as the "cost of labour turnover" (e.g., Davidson, Timo and Yang, 2010; p. 460) and "turnover cost per employee" (Reynolds, Merritt, and Gladstein, 2004; p. 230). Examples of staff turnover costs include recruitment and training cost and also reduced productivity (Davidson et al, 2010; Hinkin and Tracey, 2008). Yet an examination of widely-used management accounting texts (e.g., Drury, 2007; Horngren et al, 2011) and hotel management accounting texts (eg., Guilding, 2009; Jagels, 2007) and also the accounting research literature reveals no consideration given to how staff turnover costs should be accounted for. Anecdotal evidence suggests it is very rare for any business, hotel or otherwise, to maintain a "cost of staff turnover" account. This failure to financially monitor staff turnover can be expected to detract from efforts directed to reducing staff turnover levels and controlling staff turnover costs. It was this inconsistency between everyday HRM parlance and the reality of hotel accounting systems that prompted conduct of the study reported herein.

The objectives of the study are to:

- examine staff turnover accountability procedures adopted in hotels,

- explore hotel HRM perceptions of alternative staff turnover accountability procedures.

The hotel industry appears particularly appropriate for this study due to its labor intensity and high staff turnover (Davidson, Guilding and Timo, 2006; Yang, Wan and Fu, 2012). Labor turnover in the hotel and food service industries has been the subject of a plethora of commentaries and research (eg., Deery and Iverson, 1996; Jung, Namkung and Yoon, 2010; Robinson and Barron, 2007; Simons and Hinkin, 2001). As already noted, despite the intensity of this interest, the accounting fraternity has offered negligible insights with respect to how labor turnover costs can be monitored and what lines of accountability should be established as part of a strategy of labor turnover cost containment. This appears incongruous with Deery and Iverson's (1996) observation that heightened levels of competition are increasing the importance of hotels eliminating unnecessary costs.

The remainder of the paper is structured as follows. In the context of a literature review, the next section considers the nature of labor turnover costs and issues surrounding their accountability. Subsequent sections address, in turn, the empirical research method employed, the study's findings and a conclusion that elaborates on the significance and limitations of the study.

\section{Literary context of study and background discussion}

Considerable evidence points to the potential of staff turnover to significantly diminish hotel profitability levels. Schlesinger and Heskett (1991) report that the Marriott hotel company estimated that each percentage increase in its staff turnover rate costs between 
\$5 and \$15 million in lost revenue. In an Australian context, the Industry Assistance Commission report on Tourism Accommodation and Training (1995) estimated that the average cost of staff turnover ranges from \$AUS 4,000 for a room attendant to around \$AUS 16,000 for a senior manager (cited in Deery and Iverson, 1995). Huselid (1995) observed a strong association between lower levels of staff turnover and higher levels of sales, market value and profitability. Despite concerns over the deleterious effects of staff turnover, Pizam and Thornburg (2000) noted an absence of studies directed to determining the costs of hotel staff turnover.

More recently, there appears to have been increased attention directed to the hotel staff turnover cost issue. Hinkin and Tracey (2000) documented hidden costs associated with hotel staff turnover and developed a model that estimated the cost of employees departing from a range of positions. The model was structured around five broad cost categories, each with several cost sub-categories (see Table 1). From this model, Hinkin and Tracey estimated that for a hotel with 30 front desk employees commanding a remuneration of $\$ 12$ per hour, a 50\% staff turnover level would generate $\$ 150,000$ annual departmental costs. In a subsequent work, Hinkin and Tracey (2006) found the average cost to replace front desk personnel to be $\$ 5,864$. More recently, Davidson et al (2010) conducted a survey of Australian hotel HR managers to estimate the costs of executive and manager staff turnover as well as the cost of operational staff turnover. The following ten categories of executive and manager staff turnover costs were identified in the survey questionnaire: replacement advertising, time spent interviewing and selecting replacements, training costs, agency fees, contract staffing, uniforms, selection tests, legal costs, relocation expenses, and medicals. Their analysis of operating level staff turnover costs was based on a subset of these categories. From this analysis, Davidson et al estimated the average cost of replacing an operating level hotel employee to be AUS\$ 9,591. Further, support for the materiality of staff turnover costs comes from Simons and Hinkin (2001) who documented a statistically significant negative association between staff turnover levels and hotel profitability.

Insert Table 1 about here

Glebbeek and Bax (2004) note that much of the general management and HRM staff turnover literatures have been dominated by investigations into determinants of staff turnover. This also appears to be the case with respect to the hospitality management literature. Amongst the antecedent factors that have been noted as affecting turnover in the hospitality sector are: proportion of temporary and young staff, proportion of female staff, limited training, role conflict, lack of work autonomy and low rates of pay (Deery and Shaw, 1999; Hinkin and Tracey, 2008; Pizam and Thornburg, 2000; Yang, 2010). In addition, Deery and Iverson (1996) conclude that the presence of a turnover culture is a key factor affecting an employee's predisposition to leave an organization. Rowley and Purcell (2001) noted that hospitality managers regard an 18-month to two-year working engagement as a satisfactory return on recruitment costs and investment in training.

A problem with managing labor turnover arises from the fact that the bulk of the turnover costs are implicit rather than explicit (Hinkin and Tracey, 2008; Lashley and Chaplain, 1999). Lashley (2000) provides an overview of push and pull factors associated with 
employee turnover. Push factors concern experiences within the firm causing an employee to leave, and pull factors relate to particular attractions associated with working elsewhere. These factors are summarized in Table 2. With the possible exception of issues related to training, it appears that the 'push' factors lying behind staff turnover are predominantly traceable to the department in which an employee works and a case can therefore be made for holding operating managers accountable for the cost of staff turnover stemming from 'push' factors. It would appear inappropriate, however, to attempt to hold a manager accountable for that portion of staff turnover that is attributable to 'pull' factors.

Insert Table 2 about here

We see the absence of discussion relating to the cost of staff turnover in the accounting literature as signifying it is a cost object that lies outside the conventional accounting paradigm. This suggests deficient cost accountability and a reduced level of internal organizational visibility for staff turnover. This shortcoming appears exacerbated when we recognize that the cost is caused by a different accountability unit (i.e., the area of the organization where the employee works) to the unit that bears a significant proportion of staff turnover costs, i.e., the human resource (HR) department (Lashley, 2000). On a priori grounds, it would appear that this problem is likely to be particularly manifest in cases where the operating manager feels a degree of turnover is desirable. This is because while the manager may reap some benefit from the turnover, he or she is buffered from being charged the full costs associated with the turnover, as much of the turnover cost is charged to another department. While the total costs of the staff turnover may outweigh the benefits, if the costs as well as the benefits of turnover are not charged to the particular manager who has the greatest capacity to influence a particular staff member's decision to leave, the accounting system will not prompt the manager to carefully consider the full cost / benefit tradeoff associated with turnover. In effect, insulation from seeing the complete cost / benefit picture will result in the manager's approach to managing staff turnover being ill informed, due to the partial accounting picture provided.

In light of this, it appears reasonable to question whether the cost of staff turnover should be allocated to the operating department that has experienced (and caused) the staff turnover. For this reason, attitudes towards allocating the cost of staff turnover to operating departments have been examined in the empirical phase of this study. A priori reasoning leads us to the view that there would appear to be three ways that staff turnover costs can be charged to operating departments:

- An estimate of average HRM staff turnover costs incurred per departing employee could be charged to the operating unit experiencing an instance of staff turnover.

- A two stage charge out of HRM services could be implemented. Firstly, the variable cost associated with the departure of a former employee and the hiring and training of a new employee could be charged to the department concerned. In addition, an annual charge could be levied on all departments to cover the fixed costs associated with maintaining the HRM department. This cost allocation could be based on a formula relating to number of employees in each department or absolute number of new employees hired in each department. 
- HRM is a service centre and all, or a portion of the costs of running this service centre, could be charged to operational units in accordance with their volumes of staff turnover.

Another facet of staff turnover accountability that has been examined in this study is the conduct of exit interviews. An exit interview can assist an employer's attempts to determine why an employee chooses to leave (Evans, 2006; Rudman, 2002; Stone, 2005). Such information can assist the development of turnover reduction strategies (Kulik, Treuren and Bordia, 2012). Exit interviews have been subjected to extensive criticism from management scholars, however, as the reasons for departure cited by a leaving employee at the time of their resignation can be substantially different to the reasons they provide several months later (Feinberg and Jeppeson, 2000; Griffeth and Hom, 2001; Steel, Griffeth and Hom, 2002). To counter this problem, it has been suggested that organizations should engage experienced and independent interviewers (Giacalone, Stuckey and Beard, 1996; Steel et al, 2002) and a standardized interview format that prompts the leaver to comment on positive and negative aspects of the job and employer (Zaradona and Camuso, 1985). Eldridge (2008) found 57 percent of 316 surveyed HR practitioners indicating that their organization conducts exit interviews. This data appeared to be a relatively under utilized resource, however, as Eldridge found that only half of the organizations consolidated the collected data in an effort to identify exit patterns.

Commenting on a hotel context, Woods and Macaulay (1987) note that an exit interview can be a useful tool for locating HR related problems such as undesirable turnover or supervisory problems. In a study of seasonally affected restaurants, Reynolds, Merritt and Gladstein (2004) found that exit interviews can be used as an opportunity to secure offseason contact information in a positive manner and also to identify future development opportunities. Mok and Luk (1995) found exit interviews to be widely deployed in Hong Kong hotels, but raised a concern over the effectiveness with which the interview process assists attempts to control turnover. In a similar vein, from an analysis of exit interview data collected in two hotel chains, Williams, Harris and Parker (2008) questioned whether the potential value of exit interview data is being sufficiently exploited.

The 'Findings' section appearing below draws on agency theory as a framework facilitating the structuring of observations with respect to who is held accountable for what aspects of staff turnover in hotels. While agency theory's main origins lie in the work of Berle and Means (1932), some commentators trace the theory back to Adam Smith's (1776) The Wealth of Nations. Letza et al (2004) claim that Smith was concerned with the agency issue when claiming that directors will be less careful with others' resources than they are with their own. Agency theory has been applied extensively in financial economics, especially in research concerned with shareholder/manager interactions. This application has now broadened, with the theory being deployed in studies concerned with organizational behaviour and facets of strategic management (Eisenhardt, 1985; 1988; 1989; Kosnik 1987). The main aspects of agency theory that lie behind this breadth of applications concern its focus on conflicting interests, incentive problems and attempts to mitigate incentive problems (Lambert, 2001). More extensive reviews of agency theory application appear in Letza and Smallman (2001) and Stoney and Winstanley (2001). 
An agency relationship occurs when one or more individuals engage a second individual to provide services on their behalf (Jensen \& Meckling, 1976; Ross, 1973). The party with the capacity to call a second party to account is termed the 'principal', and the party called to account is termed the 'agent' (Baiman, 1990).

\section{Research Method}

Data were collected via an exploratory interview approach. The absence of a literature concerned with staff turnover cost accountability signifies that any attempt to formulate survey questions would have to be undertaken in the absence of any strong conceptual underpinnings. This literature absence would have compromised any attempt to develop well-informed survey questions. Our limited understanding of staff turnover accountability underscores the appropriateness of applying an exploratory and qualitative methodology. It is in light of the limited prior literature concerning the phenomenon under enquiry that an interactive approach to data collection, whereby the researcher reflexively probes deeper into views and perspectives commented on by subjects, appears particularly apt.

Interviews with twenty six managers in large three to five star hotels located in Queensland, Australia have been conducted. This region was selected as it provided ease of access for the research team and the research team are known to several hotel managers in the area. Relative to the broader population of hotels, a distinguishing characteristic of many of the hotels represented in the study concerns their significant focus on the tourism market. High tourism is generally associated with greater seasonality, a factor that is likely to make staff turnover issues more challenging. This factor suggests that the sample may be strongly placed to provide insights into relatively well developed staff turnover management procedures.

Fourteen of the hotel managers interviewed represent the HRM function. The remainder comprise: four financial controllers, four food and beverage (F\&B) managers, two housekeeping managers, one events manager and one general manager. In addition, interviews were conducted with HR managers in two theme parks. The theme park involvement resulted from an interview conducted in a hotel that is affiliated to a theme park organization. The introduction to the two theme park HRM interviewees proved to be serendipitous as their interviews yielded useful hotel labor turnover management insights provided from a distinctive perspective. An overview of the subjects interviewed is provided in Table 3. The first column provides an identifying letter for each interviewee and an indication of their functional area. The next column provides an indication of each interviewee's hotel size in terms of number of rooms and also the hotel's star rating. Subsequent columns provide, in turn, information on the hotel's: workforce composition, main activities, staff turnover accounting procedures, staff turnover benchmarking activities and a summary of the interviewee's attitude towards allocating staff turnover costs to operating departments.

Insert Table 3 about here

All interviews were recorded and ranged in duration from 30 to 75 minutes. The 
interviews were conducted in a semi-structured manner with the support of an interview schedule comprising twenty prompt questions. Interviewees were asked questions designed to ascertain the staff turnover accountability procedures currently adopted in their hotel and also questions designed to determine their perspective on what managerial implications would arise from an accounting system that allocated staff turnover costs to operating departments. All of the interviews were fully transcribed and a follow up phone call was made to two interviewees to clarify key points made during the interviews.

The transcriptions were subjected to thematic data analysis. Following the convention proposed by Miles and Huberman (1994), this analysis involved focusing on the significance and meaning of the data, determining patterns and exploring for any associations between the identified themes. The thematic analysis was independently conducted by two members of the research team and a consensus then sought for those instances where the two analyses diverged. This step was taken to promote greater reliability in the data analysis exercise. While a conscious effort was made to objectively undertake the analysis, consistent with all qualitative data based research, we cannot discount the potential of the researchers' backgrounds affecting the way the data was collected and analysed (Mertens 2004). The primary themes emerging from the data analysis were 'staff turnover accountability systems', 'staff turnover costing' and 'allocation of staff turnover costs to operating departments'. These themes have been used as the primary structuring mechanism in the presentation of findings in the next section.

\section{Findings}

Findings documented in this sub-section are structured under the following three main headings: 1) Staff turnover accountability systems, 2) Staff turnover costing, 3) Staff turnover cost allocation to operating departments.

As noted earlier, agency theory has been drawn on to facilitate the examination of a range of possible staff turnover accountability relationships. Based on a priori reasoning that draws on agency theory concepts, Table 4 has been developed to provide a framework that will afford structure to the documentation of distinct staff turnover accountability relationships and also issues arising that were commented upon by the interviewees. The table's rows constitute an overview of possible staff turnover accountability relationships. For identification purposes, each relationship has been assigned a reference code in the table's first column. The relationships coded A1 - A2 relate to conventional staff turnover accountability relationships, and the relationships coded B1 - B3 concern accountability relationships that would arise in the context of an accounting system assigning staff turnover costs to operating departments. For each accountability relationship, the principal and agent are identified (columns 2 and 3). The table's fourth column identifies the 'accountability object', which is the measurable construct that is used to monitor an agent's performance. Table 4 has also been structured to enable documentation of the relative strength of each accountability relationship depicted. The table's penultimate column provides an assessment of the strength of the accountability relationships and the final column provides a rationale for the accountability strength that has been accorded to each of the relationships. Entries made in these last two columns are based on the study's interview observations. 
Insert Table 4 about here

\subsection{Staff turnover accountability systems}

\subsubsection{Percentage staff turnover reporting}

As is evident from Table 3 , monthly percentage staff turnover monitoring was undertaken in all properties visited, with the exception of Interviewee D's property that monitored on a quarterly basis. Only Interviewee A's hotel failed to report this data on a departmental basis.

In the majority of the properties, the responsibility for property level staff turnover percentage rates was borne by the HRM manager, and for individual operating departments, by the departmental manager. This shared accountability appears inconsistent with the identification of well-defined discrete lines of responsibility that is a widely accepted internal control principle in the normative accounting literature (Guilding, 2009; Jagels, 2007). This shared responsibility appeared to be a source of tension between HRM managers and operating department managers. This is evident from the following comments:

Interviewee $\mathrm{G}$ commented:

People (ie, operating managers) are very aware of turnover and very careful with turnover in managing and monitoring it, but yes it is a little bit down the list on their priorities. This is a very strong focus with human resources.

Interviewee L commented:

For far too long in this hotel .... our human resources have been seen as the owner of all human resources activity, so line managers in many ways have abdicated their responsibility to say these are my employees. I have a responsibility to performance manage them, to develop retention based activities to keep them on board..... Line management in this business, in terms of having an accountability for retaining employees, haven't taken their responsibility seriously there.

Interviewee $\mathrm{N}$ commented:

I think they (operating managers) have minimal accountability for their staff retention. It's certainly a great area of frustration for myself and my HR team and probably for my senior executive team as well. They believe that if someone leaves, well HR can go and find me another one, which obviously doesn't assist in retention.

The first accountability relationship (labeled "Al") in Table 4 concerns the hotel's general manager acting as principal and the HRM manager acting as agent. In this relationship, the HRM's accountability focuses on the percentage of property-wide staff turnover. Several of the interviewees noted a weakness in this relationship as the HR manager has only a muted capacity to affect staff turnover levels, due to staff members' more profound and extensive interaction with their departmental heads. Interviewee $\mathrm{V}$ commented:

Its certainly going to be frustrating for an HR director held accountable for staff turnover. If an operating department manager tends to treat staff poorly, there's 
only so much influence an HR manager can exert to reduce high turnover.

The second staff turnover accountability dimension, which casts operational managers as agent and HR managers as principal, results from HR managers recording and reporting staff turnover percentage figures on a departmental basis. This accountability relationship has been designated "A2" in Table 4. The strength of this accountability relationship appears to be relatively weak because the HR manager generally has no authority over a line manager and also monetarily denominated performance measures (eg, cost of staff turnover) tend to command more attention than non-monetarily denominated measures (eg, percentage staff turnover). This view was supported by many comments made by the interviewees. For example, Interviewee B1 stated "Dollars talk", while Interviewee J commented:

Our team of managers are very, very, very financial. .... The areas in which I have most concern are the departments that make money, in food and beverage and retail. .... If you put it in black and white for them in financials, as an organization what it is costing us, what I am hoping is that they are going to get them to say 'Yes, OK, right I can understand that'.

\subsubsection{Percentage staff turnover target levels}

It was evident from the interview data that a significant factor undermining staff turnover accountability relationships stems from the elusiveness of a specific target turnover percentage. All interviewees noted that some turnover is desirable. Interviewee D commented:

I think low turnover is unhealthy.

Interviewee $\mathrm{F}$ saw $25 \%$ to $27 \%$ turnover levels as

.... not too bad ... if it is the right people turning over.

Interviewee I commented:

You need some because you need fresh blood coming in. You need fresh ideas.

There are some people who you are very, very happy to see go.

When asked for a desired level of staff turnover, Interviewee B simply responded "Too hard". This problem of establishing a turnover level target detracts from control of staff turnover, as substantial psychological research evidence suggests improved performance results when a quantified target is set (Tosi, 1975). The challenge of identifying a target level of percentage turnover was handled in Interviewee $\mathrm{W}$ and $\mathrm{X}$ 's hotels by distinguishing between positive (desirable) and negative (undesirable) turnover. In these properties, when a staff member leaves the hotel, the departure is classified by HR as a desirable or undesirable turnover incident. Both Interviewees $\mathrm{W}$ and $\mathrm{X}$ acknowledged that in some instances it can be a relatively arbitrary call whether an employee's departure should be designated positive or negative turnover.

\subsubsection{Conduct of exit interviews}

A distinct dimension of staff turnover accountability is evident in the widely-adopted practice of conducting exit interviews that involve an HRM representative meeting with a departing employee to determine reasons for the employee's resignation. This represents a form of accountability because the HRM department can draw on the collected data to determine whether there appears to be a staff management problem in a particular 
department. Interviewee A described exit interviews in the following way:

The exit interview is obviously a confidential document. .... We tell them once they have completed the exit interview that it will be for the HRM's eyes and the General Manager's eyes as well. If there is anything in that exit interview that we deem is necessary for us to bring forward and discuss with the current department or areas that we need to improve on, that is what the exit interview is going to be about.

\subsection{Staff turnover costing}

\subsubsection{Proportion of HRM budget consumed by turnover costs}

The topic of staff turnover costs was introduced in the interviews by initially posing the question: "What proportion of your hotel's HRM costs are driven by staff turnover?". Many interviewees noted that this was a difficult question to answer definitively. Some of the HR managers interviewed referred to the proportion of their staff involved full time in training and recruitment. The lowest ratio of staff turnover costs to total HRM budget referred to by any of the interviewees was $60 \%$ and the highest was $80 \%$. This underlines the high degree to which labor turnover represents a cost driver in hotel HRM departments.

It was widely held by the interviewees that most of the costs arising from staff turnover were borne by the HRM function. The most readily identifiable staff turnover costs appear to be recruitment and induction training expenses and in all sites visited, these were financed from the HRM budget. Some operating departments supplemented HRM training programs with 'on the job training' that was financed by the operating department. Although most recruitment costs were financed from the HRM department budget, in several cases HRM's expenditure was allocated as an overhead to revenue generating departments. This allocation was generally based on a formula recognizing staff number and payroll levels (not staff turnover levels). This procedure appeared to provide no contribution to promoting staff turnover accountability. When asked why this allocation was made, interviewee $\mathrm{K}$ commented in a defensive manner: "It's the way the system works here" and was unable to provide a rationale supporting this overhead allocation exercise.

\subsubsection{Incidence and nature of staff turnover costing}

Six of the hotel interviewees had been exposed to some cost of staff turnover analysis in their careers (interviewees: A, B, D, F, N and V). Interviewee A had been involved in a one-off analysis of the cost of hiring employees at a range of levels (front line, supervisor and manager) and determined that these costs ranged from \$AUS 2,000 to \$AUS 7,000. It appears, however, that this had been little more than a one-off HRM initiated cursory analysis designed to provide data that could be used to make staff turnover costs more visible to operating managers. Interviewee $\mathrm{N}$ had also been involved in a one-off operating staff turnover costing exercise that had estimated the cost to be $\$$ AUS 3,000 . Interviewee $\mathrm{N}$ noted that this number had:

.... been shared throughout the organization. This is what it costs. This is why we need to ensure the people that we have are happy. That they are well trained, looked after, nurtured, mentored, coached. 
Interviewee D had previously worked for a New Zealand hotel where the cost of replacing an operational level employee had been computed at \$AUS 3,700. This figure encompassed the main variable costs of staff turnover (i.e., recruiting and training). The interviewee commented that this exercise had been undertaken in order to draw operating managers' attention to the significance of staff turnover. The operating staff turnover costing exercise undertaken in Interviewee F's hotel had excluded HRM fixed costs from the computations.

All of the interviewees appeared to see the uncovering of the cost of staff turnover as a desirable initiative. Interviewee $\mathrm{Z}$ saw an enhanced justification of expenditure on staff retention resulting from staff turnover costing. He commented:

It is worth acknowledging the cost of it (staff turnover) and then by acknowledging the cost of it you can then put some measures in place to take a look at the cost of staff retention ... to help justify expenditure on retention.

As staff turnover costing falls outside the conventional parameters of accounting, however, several interviewees felt that such an initiative was unlikely to be initiated by, or receive much support from, the accounting function. Typifying interviewee views, Interviewee $\mathrm{G}$ commented:

We don't probably measure closely enough the actual cost of it (labor turnover). .... I think the main advantage would be in awareness. .... I don't think turnover is taken as seriously as it should be by some department heads. .... A dollar figure talks more to our managers than a percentage does, because I don't think there is much accountability. One of the reasons we monitor it is we try to make people accountable but maybe seeing a dollar amount of what it is actually costing would help a little bit more.

\subsubsection{Minimizing casual staff engagement costs}

Interviewee I felt operating managers in her organization needed to be made more aware of staff turnover costs. This property had a high proportion of casual staff, and although she noted that casual staff turnover costs are less on a per capita basis than full or parttime staff turnover costs, the quantum of casual staff employed signified that total casual staff turnover costs were significant. She commented:

We don't feel they (casual staff) are being utilized to the maximum of their employ. We have people who have ten staff, giving them two to three hours a day. We want them to try to be smarter with the utilization of their staff and have, say, six, and give them four or five hours a day. ... HR work very hard at getting those people. We haven't educated the departments about the difficulties, nor the costs, but we have highlighted that we need to do that because they can then take more ownership about retaining those people, looking after them. .... I think (some) people are aware of what the cost is. Others don't realize the time and effort and cost involved.

This interviewee felt that relative to theme parks, hotels have much greater scope for job sharing and multi-skilling within the same department. Because of this, there was a greater need for theme parks to break down a silo departmental mentality in order to reduce the number of casuals employed. With respect to this issue she commented: 
You would put somebody on the main gate of a morning 9 to 11 when you have got the bulk of the people coming in through the gates. You would let that person go down to $\mathrm{F} \& \mathrm{~B}$ for 11 to 2 . Then you would have taken two jobs and made one. You have multi-skilled that person. ..... One advantage that hotels have over us is that a hotel will offer drinks with lunch so you can normally give people a shift that takes in two of those eating times; breakfast / lunch or lunch / dinner. We have lunch. .... We rarely can put two jobs together.

In effect, this manager was pointing towards the need to reduce total staff turnover costs by employing fewer employees. Fewer employees signifies less staff turnovers costs emanating from activities such as recruitment advertising, induction processing, etc. The failure to promote staff turnover cost accountability signified limited impetus to reduce the number of employees engaged, however.

Interviewee $\mathrm{J}$ had determined that it cost \$AUS 250 to recruit a casual employee (including issue of uniform, but excluding induction training). She noted that in the previous year 73 "hired" employees had subsequently worked no hours. This is because operating managers had no incentive not to ask the HRM manager to hire more employees than were actually needed. In effect, this had signified expenditure of \$AUS18,250 (73 X \$AUS 250) for no benefit. As a result of this, Interviewee J conducted a more extensive analysis of employee recruiting costs in order to brief operating managers on how much their 'labor requisitions' were costing the company.

\subsection{Allocation of staff turnover costs to operating departments}

\subsubsection{Table 4's 'B1' accountability relationship}

Table 4's panel B depicts the staff turnover accountability relationships that would arise if staff turnover costs were to be allocated to the operating departments experiencing the turnover. Accountability relationship "B1" highlights how enhanced accountability with respect to operating departments would likely result from the allocation exercise. This is because the operating managers would be held financially accountable to the General Manager for the cost of staff turnover occurring in their department. This view appeared to be shared by many interviews as they commented on managers having a strong financial orientation in their managerial philosophy, and that this was particularly evident in profit centres. Interviewee L commented:

We want to make line management absolutely accountable and the best way to make them accountable is to hit them in the hip pocket.

Also supporting the accountability strength conclusion posited in Table 4's panel B, Interviewee $\mathrm{O}$ noted that operating manager accountability based on allocating staff turnover costs is a more powerful management tool than monitoring managers on their staff turnover percentages. He commented:

Its probably not that effective presenting figures to them and pointing out that staff turnover has gone from $37 \%$ years ago to $47 \%$ year to date., .... They really don't take much notice of it. .... As turnover and staff training doesn't affect their P\&L's directly, they don't see it as that big an issue.

From a Financial Controller's perspective, Interviewee A1 commented:

I'd certainly have it as a key KPI, as opposed to at the moment we look at financial, and in a separate meeting we look at other factors. We would benefit 
hugely by bundling it up and saying "You need to know that this department has $\mathrm{X} \%$ turnover. Last year that turnover was 'that', and this is what we believe the cost to be". I'd love to have that as part of the financial report.

In a similar vein, commenting on his hotel's monthly departmental managers' 'critique' meetings, Interviewee Y commented:

I would make it (staff turnover costing) best practice, to have it part of the critique's process. ... Stated as a side note, the cost of your departmental turnover being this great and your budget is this, would benefit the business.

Interviewee $\mathrm{X}$ was also strongly supportive of the idea of allocating staff turnover costs to operating departments. She felt it would result in operating managers assuming greater responsibility for, and engagement in, staff recruitment and training. She commented:

Departmental managers sometimes stereotypically believe it is HR's responsibility for recruitment and training. They don't see it as their responsibility, that it's their business and their staff. Every department should be treating it like their business. That cost would be their's not HR's.

Only Interviewees A and B had experienced an accounting system that allocated staff turnover costs to operating departments. Interviewee B had seen the allocation made as an imputed charge for each staff member replaced. She had gained this experience when working in the HRM department of a large US based hotel that was part of a large chain. She saw considerable merit in this accounting procedure, claiming that it caused department managers to more carefully manage their staff turnover levels. She claimed that she would have liked to introduce the system in the hotel where she worked at the time of the interview, however her HRM department was under-staffed and other priorities had hitherto precluded her attending to the matter.

\subsubsection{Table 4's 'B2' accountability relationship}

Table 4's accountability relationship "B2" represents a duplication of the "A1" relationship, whereby the HRM manager is accountable to the General Manager. A significant difference arises, however, with respect to the accountability object. In "A1", the accountability object is percentage staff turnover. In "B2" this is supplemented by the cost per unit of staff turnover. In light of the comments above concerning the enhanced power of accountability when a monetary measure is employed, the "B2" relationship has been designated 'semi-strong'.

\subsubsection{Table 4's 'B3' accountability relationship}

With respect to accountability relationship "B3", Interviewee $\mathrm{H}$ felt that assigning staff turnover costs back to operating departments might make the HRM department more accountable to other departments for its recruitment and training expenditure. Interviewee $\mathrm{H}$ even felt that this cost allocation could result in some operating departments perceiving the cost of replacing staff to be too great and might result in operating department managers promoting the idea of outsourcing the HRM function.

"B3" is a particularly interesting accountability relationship as it highlights how assigning turnover costs to operating managers promotes a reversal of the conventional principal/agent relationship depicted as "A2". In the "B3" relationship, the fact that the 
operating department is acquiring a labor recruitment service provided by the HR department is underscored by the cost transfer from the HR department to the department experiencing the staff turnover. The cost transfer associated with the provision of this service has the effect of elevating the operating manager to that of a principal equipped with knowledge of the cost quantum transferred from the HR department. From the comments made by Interviewee $\mathrm{H}$, this elevated status has the potential to carry the ultimate sanction by the purchasing party, i.e., if dissatisfaction is felt by several purchasing principals, the HRM function could become outsourced.

\subsubsection{General issues relating to allocating staff turnover costs to operating departments}

A different approach to allocating staff turnover costs to operating departments had been observed by Interviewee A. In a previous hotel job, this manager had initiated the charging back of various categories of staff turnover cost to relevant departments. He commented:

I managed to convince the manager and the general controller .... so we shifted that cost, recruitment and advertising costs etc., to the particular department, which works to a certain degree. .... At the end of the day, it all comes out of the same purse, so to speak. It was still an exercise that was valuable in determining how much is being spent on this particular department in relation to number of staff that have left.

Overall, the interviewees' attitudes to the idea of allocating staff turnover costs to operating departments were mixed. Some were very positive, while others saw problems with the idea.

Interviewee $\mathrm{D}$ felt that a downside of charging staff turnover costs back to a host department that has experienced staff turnover is that it might result in operating departments cutting back on training. This manager described the predominance of a short-termist culture amongst operating managers and felt this could result in managers seeking to protect short-term profitability by reducing training, even though this may have a longer-term negative impact on staff morale and turnover levels. Interviewee $\mathrm{M}$ was also negatively disposed to the notion of allocating staff turnover costs to operating departments. She commented:

It would be extremely distressing for a department head to look at recruitment that way. .... If I were to go to a department head and say every time you recruit for them, I'll charge them \$AUS 6,000, they'd tell me to stick my HR department up my bum because that's not what our team is here to provide. We're here to be more supportive, not a consultant.

Interviewee $\mathrm{L}$ described a range of staff related benefits that would derive from allocating staff turnover costs to operating departments. He commented:

You are going to find employees far happier in their employment because we have got managers really conscious of wanting to keep their people and develop their people. ..... You have got better communication. You have got people feeling better about their jobs. They are probably going to be delivering higher levels of service which you are going to translate to happier customers, better repeat business. That's a very simplistic way of looking at it, but I think there are a whole range of soft related issues that are going to come out of that. If our line managers are more accountable for that, I think our people will become more 
accountable for other aspects of their roles.

Interviewee $\mathrm{F}$ felt that tracing staff turnover costs to operating departments would be a valuable activity in many hotels. She felt, however, that it would not be appropriate for her hotel, as it would counter the hotel's focus on reducing its 'silo' departmental cost cutting mentality. Had this not been an important focus at the time of the interview, she felt that staff turnover cost allocations would have been a valuable accounting application, especially during periods of high staff turnover.

\section{Conclusion and discussion}

The field study data collected suggests hotel staff turnover accountability is pursued primarily via two formal processes: 1) monitoring of percentage staff turnover at the departmental level, and 2) conduct of exit interviews. With respect to percentage staff turnover monitoring, the vast majority of the sample properties maintain monthly reporting of percentage staff turnover at the departmental level. Only one hotel reported turnover on a quarterly basis and only one hotel failed to monitor staff turnover on a departmental basis. Relative to the literature, these observations constitute a high level of turnover reporting. Bacon and Berry (2005) reported that $66 \%$ of their UK sample kept labor turnover records, while Pizam and Thornburg (2000) observed $61 \%$ of their sample of US hotel HR managers reporting voluntary turnover rates. When drawing on this literary context, it should be born in mind that Bacon and Berry's sample is quite distinct, as it was based in the UK and represented large companies drawn from a cross section of industries. While Pizam and Thornburg's sample is much more comparable, it is obviously internationally distinct from the current study's sample.

Observations made suggest that the monitoring of percentage staff turnover approach to promoting staff turnover accountability is somewhat undermined by problems surrounding the identification of turnover target levels, as some turnover is regarded as desirable. Limited turnover target setting was in evidence and there was also limited benchmarking of turnover levels across properties.

The exit interview approach to promoting staff turnover accountability represents an ex post control mechanism that is designed to ascertain why a staff member resigned and whether any remedial action is required once the circumstances of the resignation have been determined. Observations made suggest exit interviews are extensively conducted in South East Queensland hotels. This observation is consistent with prior hotel research findings (Mok and Luk, 1995).

The interviewees broadly exhibited a view that hotels need to uncover stronger mechanisms for promoting greater attention directed to the staff turnover issue. This finding provided a strong justification for the study's exploration of whether an accounting process that allocates staff turnover costs to operating departments can enhance staff turnover accountability.

A staff turnover costing exercise had only been encountered by six of the twenty eight interviewees. This observation appears to be broadly in line with Pizam and Thornburg (2000) who reported that $85 \%$ of the hotel HR managers that they interviewed had never computed staff turnover costs. Despite the sample's low exposure to staff turnover 
costing, all of the interviewees felt that such a cost exercise would be a desirable accounting initiative as it would provide greater visibility to the staff turnover management issue and also assist a 'cost-benefit' analytical justification of expenditures directed to staff retention.

The allocation of staff turnover costs to operating departments had only been observed by two of the interviewees, at earlier stages in their careers. It was notable that several of the interviewees had never contemplated or heard of such an accounting procedure. The reactions to the idea of allocating staff turnover cost to departments were relatively mixed. Some interviewees felt that it would greatly raise the perceived importance of minimizing staff turnover, while others appeared to see it as an unnecessary red tape accounting exercise. No functionally differentiated opinions on this matter were noted.

The absence of prior research concerned with staff turnover accountability underscores the extent to which this study's observations constitute a novel contribution to both academic and practicing hotel manager audiences. Of particular note, no prior study has explored the notion of allocating staff turnover costs to operating departments. Observations made in the study highlight four specific organizational benefits that can derive from allocating staff turnover costs to operating departments. These are:

- The practice would result in greater operating manager effort directed towards reducing staff turnover.

- The practice would render the HRM department more accountable to the operating departments for recruitment and training costs incurred.

- If the costs of hiring employees were charged to operating departments, then operating managers would have an incentive to arrange inter-departmental job sharing schemes in order to share staff recruitment costs with other departments, thereby reducing the total number of staff recruited, and total recruitment costs incurred.

- In the absence of staff recruitment cost allocations, there is no incentive for operating managers to limit the size of the casual labor pool recruited. Comments made by interviewee $\mathbf{J}$ attest to wasted resources associated with developing a large pool of under-utilised casual staff.

Considered holistically, these observations provide strong grounds for recommending that in hotels where staff turnover is believed to constitute a significant problem worthy of greater attention from operating managers, consideration should be given to introducing an accounting process involving the allocation of staff turnover costs to the departments experiencing the loss of staff.

While these observations suggest there could be considerable organizational benefits deriving from allocating staff turnover costs to operating departments, some concerns expressed by a minority of interviewees should also be born in mind. These included:

- Reinforcement of a departmental "silo" costing mentality.

- The possibility of operating managers overzealously cutting back training activities.

- The possibility of the allocation procedure being viewed as administratively cumbersome.

A particularly novel dimension of this paper is believed to be the way that accountability relationships have been depicted, in a manner that draws on agency theory (as reflected in 
Table 4). Examination of different accountability relationships in a way that highlights which party plays a principal or agent role, and presentation of the accountability objects and accountability strengths in a tabular format, has facilitated a comparison to be made of the relative merits of the distinct turnover accountability relationships that can arise. As a result of annexing panel A (accountability relationships in a conventional staff turnover accounting context), next to panel B (accountability relationships in the presence of allocating staff turnover costs to operating departments), it is clearly evident that the second context represents a framework with a greater propensity to promote a stronger degree of staff turnover accountability. This framework may be usefully drawn upon, or extended in, further research focused on staff turnover accountabilities, or accountability relationships more generally.

In comparison to hotels, it appears theme parks present a more challenging staffing context. This is because two dimensions of high labor demand volatility are confronted by theme parks. Firstly, theme parks experience greater food and beverage (F\&B) intraday demand volatility, with a single lunch time peak demand period. Hotels, however, can spread their F\&B labor across three peak periods: breakfast, lunch and dinner. Secondly, theme parks experience greater seasonal volatility throughout the year, due to their demand being more exclusively linked to the tourism and leisure market. While many hotels also experience significant seasonality, most are not as extensively tied to the tourism and leisure markets. As theme parks appear to confront a more challenging labor management context, they would likely serve well as a context for further research focused on leading edge staff turnover accounting practices.

While the four financial controllers interviewed saw no technical factors impeding the introduction of an accounting procedure that allocates staff turnover costs to departments experiencing the turnover, it is noteworthy that several interviewees anticipated that accountants in their organization may be resistant to developing staff turnover costing systems. The likelihood of some managers' desire for more staff turnover costing being realized has to be considered in the context of the powerful influence exerted over data recording approaches by the financial accounting model. Financial accounting's external reporting orientation provides no impetus for data to be collected or cost allocations to be made in a way that might be useful to management. As long as organizations continue to be appraised by the outside world through a financial accounting reporting lens that has no need for labor turnover costing, the potential of labor turnover accounting may continue to lie largely unrealized. Such a view signifies that despite the importance of labor intensive industries developing advanced labor management techniques, HRM managers will most likely continue to be frustrated by management accounting's continuing reluctance to step out of the shadows of its financial accounting counterpart. The failure of accountants to react to the specific information needs of HRM managers in labor intensive industries suggests that Kaplan's comments made over a quarter of a century ago are deserving of reiteration today:

We need to examine why firms have tended to use for internal planning and control, the same accounting procedures used for external reporting purposes. Depreciation and asset valuation methods, inventory valuation rules, and procedures for capitalizing or expensing investments in intangible assets can be made to differ between internal and external reporting. The firm should select for internal reporting those practices that best promote incentives for achieving its strategy and objectives. (1983, p.702). 
In conclusion, it should be noted that this study suffers from all of the limitations generally associated with qualitative research. These limitations include the degree of subjectivity that is bound to be invoked by researchers when conducting interviews and analyzing qualitative data, and also the fact that the size of the sample precludes any confident generalization of findings to wider populations. For this reason, the study's findings should be viewed in an exploratory light. A potentially useful way of building on this study's initiative would be to extend the investigation by way of a survey. The survey method could broadly investigate staff turnover accounting procedures adopted and also appraise hotel manager attitudes towards alternative staff turnover accounting approaches, such as those examined in this study. 


\section{References}

Bacon, N. and Berry, B., 2005. Shareholders, Stakeholders and HRM. University of Nottingham, Nottingham.

Baiman, S., 1990. Agency Theory in Managerial Accounting: A Second Look. Accounting, Organizations and Society 15, 341-371.

Berle, A.A., and Means, C.G., 1932. The Modern Corporation and Private Property. Macmillan, New York.

Davidson, M., Guilding, C., and Timo, N., 2006. Employment, flexibility and labour market practices of domestic and MNC chain luxury hotels in Australa: Where has accountability gone? International Journal of Hospitality Management 25(2), 193-210.

Davidson, M., Timo, N. and Wang Y., 2010. How much does labour turnover cost?: A case study of Australian four- and five-star hotels. International Journal of Contemporary Hospitality Management 22(4), 451-466.

Deery, M. A. and Iverson, R. D., 1996. Enhancing productivity: Intervention strategies for employee turnover, in N. Johns (ed), Productivity management in hospitality and tourism, (pp. 68-95), Cassell, London.

Deery, M. A., and Shaw, R.N., 1999. An Investigation of the relationship between employee turnover and organizational culture. Journal of Hospitality \& Tourism Research, 23(4), 387-400.

Drury, C., 2007. Management and Cost Accounting, $7^{\text {th }}$ edition, Thomson Learning: London.

Eisenhardt, K., 1985. Control: Organizational and economic approaches. Management Science 31, 134-149.

Eisenhardt, K., 1988. Agency and institutional-theory explanations: The case of retail sales compensation. Academy of Management Journal 31, 488-511.

Eisenhardt, K., 1989. Agency theory: An assessment and review. Academy of Management Review 14(1), 57-74.

Eldridge, R., 2008. Conduct a proper analysis of exit data to find out why employees really leave. People Management 14(4), 70.

Evans, J., 2006. Exit interviews provide insight into problems. Louisana Contractor, Baton Rouge 55(1), 36.

Feinberg, R.A. and Jeppeson, N., 2000. Validity of exit interviews in retailing. Journal of Retailing and Consumer Services 7(3), 123-127.

Giacalone, R.A., Stuckey, L. and Beard, J.W., 1996. Conditions influencing biased responding in exit interviews and surveys. Organizational Development Journal 14(1), 
Glebbeek, A. C. and Bax, E.H., 2004. Is High Employee Turnover Really Harmful? An Empirical Test Using Company Records, Academy of Management Journal 47(2), 277286.

Griffeth, R.W., and Hom, P.W., 2001. Retaining valued employees. Sage, Thousand Oaks, CA.

Guilding, C., 2009. Accounting Essentials for Hospitality Managers, ButterworthHeinemann, Oxford.

Hinkin, T. and Tracey, J.B., 2000. The Cost of Turnover: Putting a Price on the Learning Curve, Cornell Hotel and Restaurant Quarterly 41(3), 14-21.

Hinkin, T. and Tracey, J.B., 2006. Development and use of a web-based tool to measure the costs of employee turnover: Preliminary Findings. Ithaca, NY: Cornell University School of Hotel Administration Center for Hospitality Research.

Hinkin, T. and Tracey, J.B., 2008. Contextual factors and cost profiles associated with employee turnover, Cornell Hotel and Restaurant Quarterly 49(1), 12-27.

Horngren, C.T., Datar, S.M., \& Rajan, M. 2011. Cost Accounting: A Managerial Emphasis, $\left(14^{\text {th }}\right.$ ed), Upper Saddle River, NJ: Prentice Hall.

Huselid, M.A., 1995., The Impact of Human-resource-management Practices on Turnover, Productivity and Corporate Financial Performance, Academy of Management Journal 38, 647-672.

Industry Assistance Commission, 1995.Tourism Accommodation and Training, Canberra.

Institute of Personnel Development, 1997. PD Labor Turnover - 1997 Survey Results IPD, London.

Jagels, M.G., 2007. Hospitality management accounting (9th ed.). John Wiley and Sons, New Jersey.

Jensen, M.C., and Meckling, W.H., 1976. Theory of the firm: managerial behavior, agency costs and ownership structure. Journal of Financial Economics 3, 305-360.

Jung, H.S., Namkung, Y., and Yoon, H.H., 2010.The effects of employees' business ethical value on person-organization fit and turnover intent in the foodservice industry International Journal of Hospitality Management 29(3), 538-546.

Kaplan, R.S., 1983. Measuring manufacturing performance: A new challenge for managerial accounting research, Accounting Review 58, 686-705.

Kosnik, R.D., 1987. Greenmail: A study of board performance in corporate governance. Administrative Science Quarterly 32(2), 163-185. 
Kulik, C.T., Treuren, G. and Bordia, P., 2012. Shocks and final straws: Using exitinterview data to examine the unfolding model's decision paths. Human Resource Management 51(1), 25-46.

Lashley, C., 2000. Hospitality Retail Management: A Unit Manager's Handbook, Butterworth-Heinemann, Oxford.

Lambert, R. A. 2001. Contracting theory and accounting. Journal of Accounting and Economics 32, 3-87.

Lashley, C. and Chaplain, A., 1999. Labour Turnover: Hidden Problem, Hidden Costs, Hospitality Review 1(1), 49-54.

Lashley, C. and Rowson B., 2000. Wasted Millions: the level and costs of staff turnover in the licensed retail sector, Huddersfield, CHME Ninth Annual Hospitality Research Conference.

Letza, S. and Smallman, C., 2001. In pure water there is a pleasure begrudged by none: on ownership, accountability and control in a privatised utility, Critical Perspectives on Accounting 12(1), 65-85.

Letza, S., Sun, X., and Kirkbride, J. 2004. Shareholding versus stakeholding: a critical view of corporate governance. Corporate Governance: An International Review 12(3), 242-262.

Maguire, M., and Shackleton, R., 1999. Hospitality and tourism, in Lindley, R.M., Wilson R.A. (eds.), Review of the Economy and Employment 1999-2000. pp. 53-62, University of Warwick, Coventry.

Mertens, D.M., 2004. Research Methods in Education and Psychology: Integrating diversity with quantitative, qualitative, and mixed methods $\left(2^{\text {nd }} e d\right)$, London: Sage Publications.

Miles, M. and Huberman, A., 1994. Qualitative Data Analysis: An Expanded Sourcebook Thousand Oaks, CA: Sage.

Mok, C. and Luk, Y., 1995. Exit interviews in hotels: Making them a more powerful management tool. International Journal of Hospitality Management 14(2), 187-194.

Pizam, A. and Thornburg, S.W., 2000. Absenteeism and voluntary turnover in Central Florida hotels: a pilot study, International Journal of Hospitality Management 19(2), 211217.

Reynolds, D., Merritt, E and Gladstein, A., 2004. Retention Tactics for Seasonal Employers: An Exploratory Study of U.S.-Based Restaurants, Journal of Hospitality \& Tourism Research 28, 230-241.

Robinson, R., and Barron, P., 2007. Developing a framework for understanding the 
impact of deskilling and standardisation on the turnover and attrition of chefs, International Journal of Hospitality Management 26(4), 913-926.

Ross, M., 1973. The economic theory of agency: The principal's problem. American Economic Review 63(2), 134-139.

Rowley G. and Purcell K., 2001. 'As cooks go, she went': is labor churn inevitable? International Journal of Hospitality Management 20, 2, 163-185.

Rudman, R., 2002. Human Resource Management in New Zealand. Pearson Education, Auckland.

Schlesinger, L.A. and Heskett, J.L., 1991. The service-driven company. Harvard Business Review 69, 71-81.

Simons T. and Hinkin, T., 2001. The Effect of Employee Turnover on Hotel Profits: A Test Across Multiple Hotels, Cornell Hotel and Restaurant Quarterly 42, 65-69.

Steel, R.P., Griffeth, R.W. and Hom, P.W., 2002. Practical retention policy for the practical manager. Academy of Management Executive 16(2), 149-162.

Stone, R., 2005. Human Resource Management. John Wiley \& Sons, Queensland.

Stoney, C. and Winstanley, D., 2001. Stakeholding: confusion or utopia? Mapping the conceptual terrain, Journal of Management Studies 38(5), 603-26.

Tosi, H., 1975. The Human Effects of managerial budgeting systems, in Livingstone, J.H. (Ed.), Management Accounting: The Behavioral Foundations. Grid. Columbus, Ohio.

Williams, D., Harris, C. and Parker, J., 2008. I love you - goodbye: Exit interviews and turnover in the New Zealand Hotel industry. New Zealand Journal of Employment Relatons 33(3), 70-90.

Wilson, R.A., 1998. UK labor market prospects. in: Lindley, R.M., Wilson R.A. (Eds.), Review of the Economy and Employment 1999-2000. pp. 1-30, University of Warwick, Coventry.

Woods, R. and Macaulay, J., 1987. Exit interviews: How to turn a file filler into a management tool. Cornell Hotel and Restaurant Administration Quarterly 28(3), 3-10.

Yang, J., 2010. Antecedents and consequences of job satisfaction in the hotel industry, International Journal of Hospitality Management 29(4), 609-619.

Yang, J., Wan, S. and Fu, Y., 2012. Qualitative examination of employee turnover and retention strategies in international tourist hotels in Taiwan, International Journal of Hospitality Management 31(3), 837-848.

Zaradona, J.L. and Camuso, M.A., 1985. A study of exit interviews: Does the last word count? Personnel 62(3). 47-48. 
TABLE 1

The costs of staff turnover

Separation Costs

Exit interviewer

Employee exit interview

Paperwork processing

Severance pay

Recruiting and attracting costs

Advertising

Search and agency fees

Internal referral fees

Managerial pre-employment administrative functions

Applicant travel

Recruiter travel

Recruiter time

Miscellaneous (correspondence, telephone, couriers)

HR pre-employment administrative functions

Selection costs

HR interview

Managerial interview

Applicant travel

Background and reference checks

Medical exam

HR administrative functions

Managerial administrative functions

\section{Hiring costs}

HR administrative functions

Managerial administrative functions

Relocation costs

Signing bonus

Orientation

Formal training

On-the-job training

Uniforms

Security

Informational literature

Lost productivity costs

Vacancy cost

Pre-departure productivity loss

Learning curve (cost incurred and lost revenue)

Errors and waste

Supervisory disruption

Peer disruption

Adapted from: Hinkin and Tracey (2000) 
TABLE 2

Push and pull causes of staff turnover

\begin{tabular}{|c|c|}
\hline Push factors & Pull factors \\
\hline Lack of training & More money \\
\hline Discontent with superiors & Better hours \\
\hline Poor organizational image & Permanent employment \\
\hline Poor terms and conditions & Alternative employment \\
\hline Uneven work patterns & Improved career prospects \\
\hline Poor pay & Improved training and development \\
\hline Unsuitable hours of work & Empowerment \\
\hline Lack of autonomy & \\
\hline Adapted from: Lashley $(2000)$ &
\end{tabular}


TABLE 3

Overview of the interviewees

\begin{tabular}{|c|c|c|c|c|c|c|}
\hline \begin{tabular}{|c|} 
Interviewee \\
reference / \\
Function
\end{tabular} & $\begin{array}{c}\text { Number of } \\
\text { Rooms }^{\text {a }} / \\
\text { Star rating }\end{array}$ & \begin{tabular}{|c|} 
Mix of \\
workforce
\end{tabular} & $\begin{array}{l}\text { Main activities } \\
\quad \& \text { market }\end{array}$ & $\begin{array}{l}\text { Nature of staff turnover } \\
\text { accounting procedures }\end{array}$ & $\begin{array}{l}\text { Staff turnover } \\
\text { benchmarking }\end{array}$ & $\begin{array}{c}\text { Attitude towards allocating staff } \\
\text { turnover costs to operating } \\
\text { departments }\end{array}$ \\
\hline $\begin{array}{c}\text { A } \\
/ \\
\text { HR. } \\
\text { Manager }\end{array}$ & $\begin{array}{c}200-250 \\
/ \\
5\end{array}$ & $\begin{array}{l}80 \text { full time } \\
\text { (FT); } \\
240 \text { part } \\
\text { time (PT); } \\
40 \text { casual }\end{array}$ & $\begin{array}{l}\text { Upmarket accommod'n, } \\
\text { fine dining, hosting } \\
\text { functions, 50\% domestic } \\
\& 50 \% \text { international. }\end{array}$ & \begin{tabular}{|c|} 
Monthly staff turnover \\
monitoring by full time, part \\
time and casual. No monitoring \\
by department.
\end{tabular} & $\begin{array}{c}\text { Hotel is not part of chain, } \\
\text { so limited to industry } \\
\text { general data and HRM } \\
\text { contacts in } 2 \text { neighboring } \\
\text { hotels. }\end{array}$ & $\begin{array}{l}\text { Supportive of the notion. Had } \\
\text { implemented a degree of cost assignment } \\
\text { by charging some specific turnover costs } \\
\text { (recruitment and advertising) to operating } \\
\text { departments. }\end{array}$ \\
\hline $\begin{array}{c}\text { B } \\
/ \\
\text { HR. } \\
\text { Manager }\end{array}$ & $\begin{array}{c}400-450 \\
/ \\
4.5\end{array}$ & 180 & $\begin{array}{l}\text { Accommod'n, F\&B, } \\
\text { conference functions, } \\
50 \% \text { domestic \& } 50 \% \\
\text { leisure inbound. }\end{array}$ & \begin{tabular}{|c|} 
Monthly staff turnover \\
monitoring by department, plus \\
extensive review of exit \\
interview data.
\end{tabular} & $\begin{array}{l}\text { Minimal. The hotel is one } \\
\text { of two owned by the } \\
\text { owner, but the other is in } \\
\text { a very different market. }\end{array}$ & $\begin{array}{l}\text { Very positive. Had experienced turnover } \\
\text { cost allocation to operating departments in } \\
\text { a US hotel and believed it motivated } \\
\text { managers to reduce staff turnover levels. }\end{array}$ \\
\hline $\begin{array}{c}\mathrm{C} \\
\text { / } \\
\text { HR. } \\
\text { Manager }\end{array}$ & $\begin{array}{c}600-650 \\
/ \\
4.5\end{array}$ & $\begin{array}{l}800(70 \% \\
\text { FT })\end{array}$ & $\begin{array}{l}\text { Accommod'n, F\&B, } \\
\text { conferences, casino. }\end{array}$ & \begin{tabular}{|} 
Monthly staff turnover and \\
absenteeism monitored by \\
department. Low turnover rate \\
signifies it is not reviewed \\
extensively. High importance \\
attached to exit interviews.
\end{tabular} & \begin{tabular}{|c|} 
Limited, as not part of a \\
chain. Casino staff \\
turnover is benchmarked \\
to industry via a password \\
protected website.
\end{tabular} & $\begin{array}{l}\text { Very supportive. Was aware of the idea and } \\
\text { feels it should be adopted in the hotel. } \\
\text { Acknowledged, however, that other } \\
\text { management priorities might preclude this } \\
\text { happening in immediate future. }\end{array}$ \\
\hline $\begin{array}{c}\text { D } \\
/ \\
\text { HR. } \\
\text { Manager }\end{array}$ & $\begin{array}{c}250-300 \\
/ \\
4.5\end{array}$ & $\begin{array}{c}220 \\
\text { (161 FT } \\
\text { equivalents) }\end{array}$ & $\begin{array}{l}\text { Accommod'n, F\&B, } \\
\text { Gaming. Leisure and } \\
\text { conference market. }\end{array}$ & $\begin{array}{l}\text { Quarterly staff turnover } \\
\text { monitoring by department }\end{array}$ & $\begin{array}{c}\text { Benchmark to other } \\
\text { properties within the hotel } \\
\text { chain. }\end{array}$ & $\begin{array}{l}\text { Positive about costing staff turnover, but } \\
\text { questioned the merits of allocating the } \\
\text { costs to operating departments. }\end{array}$ \\
\hline $\begin{array}{c}\text { E } \\
/ \\
\text { HR. } \\
\text { Manager }\end{array}$ & $300-350$ & $\begin{array}{l}310-450 \\
40-50 \% \\
\text { casual }\end{array}$ & $\begin{array}{c}\text { Family resort } \\
\text { accommod'n, F\&B, } \\
\text { outdoor activities. }\end{array}$ & $\begin{array}{c}\text { Monthly staff turnover } \\
\text { monitoring by department }\end{array}$ & $\begin{array}{l}\text { Benchmarking achieved } \\
\text { informally through } \\
\text { industry contacts. }\end{array}$ & $\begin{array}{l}\text { As hotel complex was relatively new, } \\
\text { HRM manager felt that other priorities } \\
\text { precluded development of staff turnover } \\
\text { costing procedures at time of interview. }\end{array}$ \\
\hline $\begin{array}{c}\mathrm{F} \\
/ \\
\text { HR. } \\
\text { Manager }\end{array}$ & $\begin{array}{c}450-500 \\
/ \\
4\end{array}$ & \begin{tabular}{|c|}
447 (including \\
98 casuals)
\end{tabular} & $\begin{array}{l}\text { Resort accommod'n, } \\
\text { F\&B, golf, extensive } \\
\text { outdoor family-based } \\
\text { activities, residential, } \\
\text { conferences. }\end{array}$ & \begin{tabular}{|c|} 
Following high levels of staff \\
turnover, HRM had \\
supplemented monthly \\
departmental staff turnover \\
monitoring by conducting a \\
cost of staff turnover analysis.
\end{tabular} & $\begin{array}{c}\text { Quarterly benchmarking } \\
\text { to other properties within } \\
\text { the hotel chain. }\end{array}$ & $\begin{array}{l}\text { Felt it could be a valuable activity in many } \\
\text { hotels, however would counter the } \\
\text { management culture pursued in hotel F } \\
\text { which attempts to break down silo cost } \\
\text { cutting mentality and promote a collective } \\
\text { revenue creation mentality. }\end{array}$ \\
\hline
\end{tabular}




\begin{tabular}{|c|c|c|c|c|c|c|}
\hline $\begin{array}{c}\text { G } \\
/ \\
\text { HR. } \\
\text { Manager }\end{array}$ & $\begin{array}{c}400-450 \\
/ \\
3.5\end{array}$ & $230-240$ & \begin{tabular}{|c|} 
Family accommod'n, \\
F\&B, 80\% leisure \\
domestic \& $20 \%$ leisure \\
inbound.
\end{tabular} & $\begin{array}{l}\text { Departmental staff turnover } \\
\text { recorded in a monthly } \\
\text { management report. }\end{array}$ & $\begin{array}{c}\text { Benchmark to other } \\
\text { properties within the hotel } \\
\text { chain. }\end{array}$ & $\begin{array}{l}\text { Initially highly sceptical, however as the } \\
\text { interview proceeded, the interviewee's } \\
\text { apparent scepticism receded. }\end{array}$ \\
\hline $\begin{array}{c}\mathrm{H} \\
/ \\
\text { HR. } \\
\text { Manager }\end{array}$ & $\begin{array}{c}350-400 \\
/ \\
4.5\end{array}$ & $\begin{array}{c}163 \text { FT or PT; } \\
40 \text { casual }\end{array}$ & \begin{tabular}{|c|} 
Accommod'n, F\&B, \\
$50 \%$ domestic $50 \%$ \\
inbound (predominantly \\
Asia).
\end{tabular} & $\begin{array}{l}\text { Hotel is not part of a chain; } \\
\text { interviewee felt reporting } \\
\text { systems are basic as a result. } \\
\text { Monthly staff turnover } \\
\text { monitored by department. }\end{array}$ & $\begin{array}{c}\text { No benchmarking } \\
\text { pursued, just informal } \\
\text { "gut feel" for industry } \\
\text { averages. }\end{array}$ & $\begin{array}{l}\text { Supportive of tracking the cost of staff } \\
\text { turnover to departmental heads. Felt that it } \\
\text { was unlikely to be adopted in the } \\
\text { foreseeable future due to a poor working } \\
\text { relationship with finance department. }\end{array}$ \\
\hline $\begin{array}{c}\text { I } \\
/ \\
\text { HR. } \\
\text { Manager }\end{array}$ & N/A & $\begin{array}{l}1,500- \\
2,500.60 \% \\
\text { casual. }\end{array}$ & $\begin{array}{l}\text { Theme park, } 70 \% \\
\text { domestic (local and } \\
\text { inter-state), } 30 \% \\
\text { international. }\end{array}$ & $\begin{array}{c}\text { Departmental staff turnover } \\
\text { analysed by seniority and } \\
\text { reported monthly to executive } \\
\text { committee. }\end{array}$ & $\begin{array}{l}\text { No formalised } \\
\text { benchmarking achieved, } \\
\text { merely conscious of } \\
\text { industry averages. }\end{array}$ & $\begin{array}{l}\text { Had never contemplated and somewhat } \\
\text { resistant to allocating staff turnover costs } \\
\text { to operating department. Thought it would } \\
\text { be too hard to "transfer cash". }\end{array}$ \\
\hline $\begin{array}{c}\text { J } \\
/ \\
\text { HR. } \\
\text { Manager }\end{array}$ & N/A & $\begin{array}{l}400-750 \\
\text { staff. } \\
\text { Up to } 80 \% \\
\text { casual. }\end{array}$ & $\begin{array}{l}\text { Theme park, } 80 \% \\
\text { domestic. }\end{array}$ & $\begin{array}{l}\text { Monthly departmental staff } \\
\text { turnover monitoring. }\end{array}$ & $\begin{array}{c}\text { Staff turnover compared } \\
\text { to industry averages } \\
\text { informally. }\end{array}$ & $\begin{array}{l}\text { Very positively disposed to allocating staff } \\
\text { turnover costs to departments as } \\
\text { interviewee felt operating managers were } \\
\text { very focused on their financial } \\
\text { performance. }\end{array}$ \\
\hline $\begin{array}{c}\text { K } \\
/ \\
\text { HR. } \\
\text { Manager }\end{array}$ & $\begin{array}{c}400-450 \\
/ \\
4.5\end{array}$ & $\begin{array}{c}230 \\
\text { (approx. } \\
115 \text { casual) }\end{array}$ & $\begin{array}{l}\text { Inbound tourist } \\
\text { accommod'n, some } \\
\text { conferencing. }\end{array}$ & \begin{tabular}{|c|} 
Monthly staff turnover \\
monitored by department. Exit \\
interview data viewed as \\
important.
\end{tabular} & $\begin{array}{l}\text { Conducted periodically. } \\
\text { Perceived as } \\
\text { problematical due to } \\
\text { hotels operating in } \\
\text { different contexts. }\end{array}$ & $\begin{array}{l}\text { Felt that allocating recruitment and new } \\
\text { staff training costs based on staff turnover } \\
\text { would result in better turnover } \\
\text { management than allocating HRM costs to } \\
\text { departments based on staff numbers and } \\
\text { size of payroll. }\end{array}$ \\
\hline $\begin{array}{c}\text { L } \\
/ \\
\text { HR. } \\
\text { Manager }\end{array}$ & $\begin{array}{c}400-450 \\
/ \\
4\end{array}$ & $\begin{array}{l}125 \mathrm{FT}, \\
70 \text { casuals } \\
\text { (house- } \\
\text { keeping is } \\
\text { outsourced) }\end{array}$ & $\begin{array}{l}\text { Predominantly Asian } \\
\text { inbound tourist } \\
\text { accommod'n, } \\
\text { conferences. }\end{array}$ & \begin{tabular}{|c|} 
Monthly staff turnover \\
monitored by department. On- \\
line exit interviews conducted.
\end{tabular} & $\begin{array}{c}\text { Benchmark across } \\
\text { properties in the group. }\end{array}$ & $\begin{array}{l}\text { Very positive. HR director asked the } \\
\text { researcher to visit the hotel again to meet } \\
\text { the General Manager and outline the } \\
\text { potential of allocating staff turnover costs } \\
\text { to operating departments. }\end{array}$ \\
\hline $\begin{array}{c}\text { M } \\
/ \\
\text { HR. } \\
\text { Manager }\end{array}$ & $\begin{array}{c}300-350 \\
/ \\
5\end{array}$ & $\begin{array}{c}340 \\
\text { permanent; } \\
60 \text { casual. }\end{array}$ & \begin{tabular}{|c|} 
Inbound tour groups \\
(predominantly \\
Japanese), conferences
\end{tabular} & \begin{tabular}{|c|} 
Recently commenced staff \\
turnover monitoring by \\
department. Developing an exit \\
interview system at the time of \\
interview.
\end{tabular} & $\begin{array}{l}\text { Attempted across group, } \\
\text { however undermined by } \\
\text { different working } \\
\text { contexts and poor data } \\
\text { collection. }\end{array}$ & $\begin{array}{l}\text { Negatively disposed to the idea. } \\
\text { Interviewee felt it would result in the HR } \\
\text { department being perceived by operating } \\
\text { managers as a consultancy rather than a } \\
\text { supportive unit, and it would be hard to } \\
\text { accurately cost staff turnover. }\end{array}$ \\
\hline
\end{tabular}




\begin{tabular}{|c|c|c|c|c|c|c|}
\hline $\begin{array}{c}\mathrm{N} \\
/ \\
\text { HR. } \\
\text { Manager }\end{array}$ & $\begin{array}{c}300-350 \\
/ \\
5\end{array}$ & $\begin{array}{c}450 \\
\text { permanent; } \\
200 \text { casual. }\end{array}$ & $\begin{array}{c}\text { Asian inbound, } \\
\text { extensive conference and } \\
\text { function facilities. }\end{array}$ & \begin{tabular}{|c|} 
Monthly staff turnover \\
monitored by department and \\
cost centre within departments \\
(67 cost centres). Exit \\
interviews conducted.
\end{tabular} & $\begin{array}{l}\text { Benchmark to data } \\
\text { provided by the } \\
\text { Queensland Hotels } \\
\text { Association. }\end{array}$ & $\begin{array}{c}\text { HR manager had contemplated allocating } \\
\text { HR costs to operating departments on an } \\
\text { employee recruitment basis, but claimed } \\
\text { that "Our accounting systems are not } \\
\text { geared to do that". }\end{array}$ \\
\hline $\begin{array}{c}\mathrm{O} \\
/ \\
\text { HR. } \\
\text { Manager }\end{array}$ & $\begin{array}{c}250-300 \\
/ \\
5\end{array}$ & $\begin{array}{c}180 \\
\text { permanent; } \\
65 \text { casual }\end{array}$ & \begin{tabular}{|c|} 
Inbound tourist \\
accommodation $(50 \%$ of \\
guests are Asian \\
tourists), conferences.
\end{tabular} & \begin{tabular}{|c|} 
Monthly staff turnover \\
monitored by department. \\
Exit interviews conducted for \\
most staff leaving.
\end{tabular} & \begin{tabular}{|c|} 
Conduct comparisons \\
with other hotels in group \\
and industry averages.
\end{tabular} & $\begin{array}{l}\text { Positively disposed, but felt that it is very } \\
\text { important that staff turnover cost } \\
\text { allocation exercise is conducted accurately } \\
\text { and perceived to be fair. }\end{array}$ \\
\hline $\begin{array}{c}\mathrm{P} \\
/ \\
\text { HR. } \\
\text { Manager }\end{array}$ & $\begin{array}{c}400-450 \\
/ \\
4.5\end{array}$ & $\begin{array}{c}100 \\
\text { permanent; } \\
60-80 \\
\text { casual }\end{array}$ & $\begin{array}{l}\text { 70\% Asian inbound, } \\
\text { minimal domestic. }\end{array}$ & $\begin{array}{l}\text { Monthly staff turnover } \\
\text { monitored by department. } \\
\text { Exit interviews conducted. }\end{array}$ & $\begin{array}{l}\text { Significant degree of } \\
\text { benchmarking across } \\
\text { properties in the group. }\end{array}$ & $\begin{array}{l}\text { Had not been exposed to the idea despite } \\
\text { attending a seminar which involved brain } \\
\text { storming on how to manage staff turnover. } \\
\text { Was positively disposed to the idea and } \\
\text { claimed it would be raised with the } \\
\text { General Manager. }\end{array}$ \\
\hline $\begin{array}{c}\mathrm{Q} \\
/ \\
\mathrm{F} \& \mathrm{~B} \\
\text { Director }\end{array}$ & $\begin{array}{c}550-600 \\
/ \\
5\end{array}$ & $\begin{array}{c}60 \% \\
\text { permanent; } \\
40 \% \text { casual }\end{array}$ & $\begin{array}{l}\text { Conferences; } \\
3 \text { restaurants; } \\
60 \% \text { international; } \\
40 \% \text { domestic }\end{array}$ & $\begin{array}{l}\text { Monthly staff turnover } \\
\text { monitored by department. } \\
\text { Exit interviews conducted. }\end{array}$ & \begin{tabular}{|c|} 
Limited benchmarking \\
due to perceived problem \\
of desirable and \\
undesirable turnover. \\
\end{tabular} & $\begin{array}{l}\text { Felt it would be hard to track using an } \\
\text { estimate of cost as real cost is too hard to } \\
\text { determine. }\end{array}$ \\
\hline $\begin{array}{c}\mathrm{R} \\
/ \\
\text { General } \\
\text { Manager }\end{array}$ & $\begin{array}{c}250-300 \\
/ \\
4.5\end{array}$ & $\begin{array}{c}30 \% \\
\text { permanent; } \\
70 \% \text { casual }\end{array}$ & $\begin{array}{l}40 \% \text { inbound; } \\
60 \% \text { domestic. Large } \\
\text { conference activity. }\end{array}$ & \begin{tabular}{|c|} 
Weekly and monthly \\
departmental staff turnover \\
monitoring. Exit interviews are \\
'critical'.
\end{tabular} & $\begin{array}{l}\text { No benchmarking as there } \\
\text { is a problem with assuring } \\
\text { accurate data. }\end{array}$ & $\begin{array}{l}\text { Felt that it would result in managers } \\
\text { attaching greater importance to careful } \\
\text { management of staff turnover. }\end{array}$ \\
\hline $\begin{array}{c}\text { S } \\
/ \\
\text { F\&B } \\
\text { Director }\end{array}$ & $\begin{array}{c}150-200 \\
/ \\
4.5\end{array}$ & $\begin{array}{c}25 \% \\
\text { permanent; } \\
75 \% \text { casual }\end{array}$ & $\begin{array}{c}20 \% \text { inbound; } \\
80 \% \text { domestic. } \\
\text { Significant conference } \\
\text { activity. }\end{array}$ & $\begin{array}{l}\text { Monthly staff turnover } \\
\text { monitored by department. } \\
\text { Exit interviews conducted. }\end{array}$ & $\begin{array}{l}\text { No benchmarking } \\
\text { undertaken. }\end{array}$ & $\begin{array}{l}\text { Felt it could be a useful tool to underscore } \\
\text { importance of turnover management. }\end{array}$ \\
\hline $\begin{array}{c}\mathrm{T} \\
/ \\
\text { House- } \\
\text { keeping } \\
\text { manager }\end{array}$ & $\begin{array}{c}400-450 \\
/ \\
5\end{array}$ & $\begin{array}{c}25 \% \\
\text { permanent; } \\
75 \% \text { casual }\end{array}$ & $\begin{array}{l}\text { Mix of leisure and } \\
\text { corporate clients. } \\
60 \% \text { international; } \\
40 \% \text { domestic. }\end{array}$ & $\begin{array}{l}\text { Monthly staff turnover } \\
\text { monitored by department - } \\
\text { annual target is } 35 \% \text {. } \\
\text { Exit interviews conducted. }\end{array}$ & $\begin{array}{c}\text { Have tried benchmarking } \\
\text { exercises, but } \\
\text { organisations sensitive } \\
\text { about data sharing. }\end{array}$ & $\begin{array}{l}\text { Thought it would result in greater resolve } \\
\text { directed to effective recruitment by } \\
\text { department heads. However, unlikely to be } \\
\text { adopted due to company wide } \\
\text { standardized accounting procedures. }\end{array}$ \\
\hline
\end{tabular}




\begin{tabular}{|c|c|c|c|c|c|c|}
\hline $\begin{array}{c}\mathrm{U} \\
/ \\
\text { F\&B } \\
\text { Manager }\end{array}$ & $\begin{array}{c}400-450 \\
/ \\
5\end{array}$ & $\begin{array}{l}\text { FT: } 50 \% \\
\text { PT: } 40 \% \text {; } \\
\text { Casual: } \\
10 \%\end{array}$ & $\begin{array}{l}\text { Conferences; } \\
2 \text { restaurants; } \\
15 \% \text { international; } \\
85 \% \text { domestic. }\end{array}$ & $\begin{array}{l}\text { Monthly staff turnover } \\
\text { monitored by department. } \\
\text { Turnover is a KPI. } \\
\text { Exit interviews conducted. }\end{array}$ & \begin{tabular}{|c|} 
High degree of \\
benchmarking data shared \\
within the group and \\
some industry data. \\
\end{tabular} & $\begin{array}{l}\text { Felt that allocation is a great idea as it will } \\
\text { make the 'evidence more stark'. }\end{array}$ \\
\hline $\begin{array}{c}\mathrm{V} \\
/ \\
\text { Events } \\
\text { Manager }\end{array}$ & $\begin{array}{c}300-350 \\
/ \\
5\end{array}$ & $\begin{array}{c}75 \% \text { FT; } \\
25 \% \text { casual }\end{array}$ & $\begin{array}{l}\text { Conferences; } \\
30 \% \text { international; } \\
70 \% \text { domestic. }\end{array}$ & $\begin{array}{l}\text { Monthly staff turnover } \\
\text { monitored by department. } \\
\text { Exit interviews conducted. }\end{array}$ & $\begin{array}{c}\text { Benchmarking data } \\
\text { shared within the group. }\end{array}$ & $\begin{array}{c}\text { Felt it would be hard to achieve a system } \\
\text { of cost allocation. Has seen staff turnover } \\
\text { cost calculated to raise visibility of the } \\
\text { issue. }\end{array}$ \\
\hline $\begin{array}{c}\mathrm{W} \\
/ \\
\text { F\&B } \\
\text { Director }\end{array}$ & $\begin{array}{c}350-400 \\
/ \\
4.5\end{array}$ & $\begin{array}{l}65 \% \text { casual; } \\
35 \% \text { FT. }\end{array}$ & $\begin{array}{l}20 \% \text { international; } \\
70 \% \text { domestic; } \\
10 \% \text { conferences. }\end{array}$ & $\begin{array}{l}\text { Monthly staff turnover } \\
\text { monitored by department and } \\
\text { distinction drawn between } \\
\text { positive and negative turnover. } \\
\text { Exit interviews conducted. }\end{array}$ & $\begin{array}{l}\text { Benchmarking is } \\
\text { undertaken at the property } \\
\text { level but not at the } \\
\text { departmental level. }\end{array}$ & $\begin{array}{l}\text { Very positively disposed to the idea. } \\
\text { Referred to executive vs supervisory } \\
\text { levels of staff and felt this would be a } \\
\text { technique that would cause supervisors to } \\
\text { attach greater importance to minimizing } \\
\text { undesirable staff turnover. }\end{array}$ \\
\hline $\begin{array}{c}\mathrm{X} \\
/ \\
\text { House- } \\
\text { keeping } \\
\text { manager }\end{array}$ & $\begin{array}{c}250-300 \\
/ \\
5\end{array}$ & $\begin{array}{l}\text { FT: } 20 \% \\
\text { PT: } 70 \% \text {; } \\
\text { Casual: } \\
10 \%\end{array}$ & $\begin{array}{l}\text { Conferences; } \\
15 \% \text { international; } \\
85 \% \text { domestic. }\end{array}$ & $\begin{array}{l}\text { \% staff turnover used as a KPI. } \\
\text { Monthly departmental staff } \\
\text { turnover monitored. Positive } \\
\text { and negative turnover } \\
\text { distinguished. Exit interviews } \\
\text { conducted. }\end{array}$ & $\begin{array}{c}\text { Benchmarking } \\
\text { undertaken at the property } \\
\text { level. }\end{array}$ & $\begin{array}{l}\text { Very positive to the idea. It would cause } \\
\text { departmental managers to more strongly } \\
\text { appreciate that recruitment and training is } \\
\text { their responsibility, not the responsibility } \\
\text { of the HR department. }\end{array}$ \\
\hline $\begin{array}{c}\mathrm{Y} \\
/ \\
\text { Financial } \\
\text { Controller }\end{array}$ & $\begin{array}{c}300-350 \\
/ \\
5\end{array}$ & $\begin{array}{c}40 \% \\
\text { permanent; } \\
60 \% \text { casual }\end{array}$ & $\begin{array}{l}70 \% \text { leisure; } 30 \% \\
\text { conference related. } \\
80 \% \text { domestic; } 20 \% \\
\text { international. }\end{array}$ & $\begin{array}{c}\text { Monthly staff turnover } \\
\text { monitored by department and } \\
\text { whole property. Distinction } \\
\text { made between positive and } \\
\text { negative turnover. Exit } \\
\text { interviews conducted. } \\
\end{array}$ & $\begin{array}{c}\text { Benchmarked to } \\
\text { Australian and Asia } \\
\text { Pacific properties within } \\
\text { the chain. }\end{array}$ & $\begin{array}{l}\text { Saw large value in raising the profile of } \\
\text { staff turnover by including the cost of staff } \\
\text { turnover in monthly reports of departmental } \\
\text { financial performances. }\end{array}$ \\
\hline $\begin{array}{c}\mathrm{Z} \\
/ \\
\text { Financial } \\
\text { Controller }\end{array}$ & $\begin{array}{c}400-450 \\
/ \\
5\end{array}$ & $\begin{array}{l}\text { Full time: } \\
\text { 50\%; } \\
\text { Casual: } \\
50 \%\end{array}$ & $\begin{array}{l}\text { Conferences; } \\
2 \text { restaurants; } \\
25 \% \text { international; } \\
75 \% \text { domestic. }\end{array}$ & $\begin{array}{l}\text { Monthly staff turnover } \\
\text { monitored by department. } \\
\text { Exit interviews conducted. }\end{array}$ & $\begin{array}{c}\text { Benchmarking conducted } \\
\text { within the chain, plus } \\
\text { some industry data } \\
\text { analysis. }\end{array}$ & $\begin{array}{l}\text { Staff turnover cost allocation would help } \\
\text { managers justify their expenditure on staff } \\
\text { retention. }\end{array}$ \\
\hline $\begin{array}{c}\text { A1 } \\
/ \\
\text { Financial } \\
\text { Controller }\end{array}$ & $\begin{array}{c}350-400 \\
/ \\
4.5\end{array}$ & $\begin{array}{l}60 \% \text { casual; } \\
40 \% \text { FT. }\end{array}$ & $\begin{array}{l}25 \% \text { international; } \\
75 \% \text { domestic. }\end{array}$ & $\begin{array}{l}\text { Monthly staff turnover } \\
\text { monitored by department. Exit } \\
\text { interviews conducted. }\end{array}$ & $\begin{array}{l}\text { Benchmarking is } \\
\text { undertaken at the property } \\
\text { level but not at the } \\
\text { departmental level. }\end{array}$ & $\begin{array}{l}\text { Positively disposed to using staff turnover } \\
\text { costs as a KPI in monthly departmental } \\
\text { reports. }\end{array}$ \\
\hline
\end{tabular}




\begin{tabular}{|c|c|c|c|c|c|c|}
\hline $\begin{array}{c}\text { B1 } \\
/ \\
\text { Financial } \\
\text { Controller }\end{array}$ & $\begin{array}{c}250-300 \\
/ \\
5\end{array}$ & $\begin{array}{c}50 \% \\
\text { permanent; } \\
50 \% \text { casual }\end{array}$ & $\begin{array}{l}\text { Significant conference } \\
\text { activity. } 80 \% \text { domestic; } \\
20 \% \text { international. }\end{array}$ & $\begin{array}{l}\text { Monthly departmental \% staff } \\
\text { turnover monitoring. Exit } \\
\text { interviews conducted. }\end{array}$ & $\begin{array}{l}\text { Main benchmarking } \\
\text { activity is to establish } \\
\text { trend data. }\end{array}$ & $\begin{array}{l}\text { Felt that the technique has merit as } \\
\text { 'dollars talk'. Felt it was unlikely to be } \\
\text { adopted, due to company wide standard } \\
\text { accounting practices. }\end{array}$ \\
\hline
\end{tabular}

${ }^{\text {a }}$ Stated as a 50 room range to facilitate the researcher's pledge of anonymity for the subjects. 


\section{TABLE 4}

Staff turnover cost accountability relationships: an investigative framework

\begin{tabular}{|c|c|c|c|c|c|}
\hline \multicolumn{7}{|c|}{ Conventional staff turnover accountability } \\
\hline $\begin{array}{c}\text { Accountability } \\
\text { relationship } \\
\text { identifier }\end{array}$ & Principal & Agent & $\begin{array}{c}\text { Accountability } \\
\text { object }\end{array}$ & $\begin{array}{c}\text { Strength of } \\
\text { accountability }\end{array}$ & $\begin{array}{c}\text { Rationale for } \\
\text { accountability } \\
\text { strength }\end{array}$ \\
\hline A1 & $\begin{array}{c}\text { General } \\
\text { manager }\end{array}$ & $\begin{array}{c}\text { HRM } \\
\text { manager }\end{array}$ & $\begin{array}{c}\text { Percentage } \\
\text { staff turnover }\end{array}$ & Weak & $\begin{array}{c}\text { Muted influence of } \\
\text { HRM manager; } \\
\text { no \$ power }\end{array}$ \\
\hline A2 & $\begin{array}{c}\text { HRM } \\
\text { manager }\end{array}$ & $\begin{array}{c}\text { Operational } \\
\text { manager }\end{array}$ & $\begin{array}{c}\text { Percentage } \\
\text { staff turnover }\end{array}$ & Weak & $\begin{array}{c}\text { No line authority; } \\
\text { no \$ power. }\end{array}$ \\
\hline Btaff turnover accountability in presence of allocating costs to operating departments \\
\hline B1 & $\begin{array}{c}\text { General } \\
\text { manager }\end{array}$ & $\begin{array}{c}\text { Panel B } \\
\text { Operational } \\
\text { manager }\end{array}$ & $\begin{array}{c}\text { Cost of staff } \\
\text { turnover }\end{array}$ & Strong & $\begin{array}{c}\text { Power of \$ } \\
\text { combined with } \\
\text { authority. }\end{array}$ \\
\hline B2 & $\begin{array}{c}\text { General } \\
\text { manager }\end{array}$ & $\begin{array}{c}\text { HRM } \\
\text { manager }\end{array}$ & $\begin{array}{c}\text { Cost per unit of } \\
\text { staff turnover } \\
\text { and percentage } \\
\text { staff turnover }\end{array}$ & Semi-strong & $\begin{array}{c}\text { Constrained influence } \\
\text { of HRM manager } \\
\text { over turnover costs } \\
\text { and volume. }\end{array}$ \\
\hline B3 & $\begin{array}{c}\text { Operational } \\
\text { manager }\end{array}$ & $\begin{array}{c}\text { HRM } \\
\text { manager }\end{array}$ & $\begin{array}{c}\text { Cost per unit of } \\
\text { staff turnover }\end{array}$ & Weak & $\begin{array}{c}\text { No line authority; } \\
\text { HRM's constrained } \\
\text { cost influence. }\end{array}$ \\
\hline
\end{tabular}

